Meta

Journal des traducteurs

Translators' Journal

\title{
Nietzsche as precursor of postmodern translation studies
}

\section{Liming Chen}

Volume 64, numéro 3, décembre 2019

URI : https://id.erudit.org/iderudit/1070540ar

DOI : https://doi.org/10.7202/1070540ar

Aller au sommaire du numéro

\section{Éditeur(s)}

Les Presses de l’Université de Montréal

\section{ISSN}

0026-0452 (imprimé)

1492-1421 (numérique)

Découvrir la revue

Citer cet article

Chen, L. (2019). Nietzsche as precursor of postmodern translation studies. Meta, 64(3), 794-816. https://doi.org/10.7202/1070540ar

\section{Résumé de l'article}

En termes d'études postmodernes de traduction, le précurseur le plus reconnu est sans doute Friedrich Nietzsche (Erickson 2001 : 84), dont la pensée philosophique postmoderne se manifeste principalement sous ces formes : Antéchrist (rejet de tout attachement à Dieu), appel à une réévaluation de toutes les valeurs, négation de la métaphysique conventionnelle, insistance sur le perspectivisme, rejet de la rationalité des Lumières, valorisation de la volonté de puissance. La pensée philosophique de Nietzsche ainsi que ses réflexions sur la traduction jouent un rôle très important dans les études postmodernes de traduction, en détrônant l'auteur en tant que Dieu du texte, en libérant le traducteur et en ouvrant l'espace signifiant à la multi-potentialité interprétative. En même temps, ses idées visionnaires ont aidé les traducteurs à se délivrer de la remise en question éthique de leur re-créativité/réécriture, à les encourager à mettre en jeu leur subjectivité de traducteur et, partant, à élargir l'horizon des études en traduction. Les idées principales de Nietzsche, telles que le perspectivisme dans l'interprétation, la réévaluation des valeurs chrétiennes, le sens historique du passé et, notamment, la conquête des Anciens par la traduction, se sont réfractées aussi dans ses réflexions sur (les études de) la traduction. Bien qu'elles ne soient pas tellement systématiques, celles-ci ont ouvert la voie à une approche postmoderne en matière d'études de traduction et ont exercé une influence durable et profonde sur ses partisans, comme Heidegger, Gadamer, Benjamin, Pound, Derrida, Steiner, Lefebvre, Venuti, etc. Une investigation rétrospective sur les idées perspicaces de Nietzsche pourra sans doute nous aider à clarifier la filiation généalogique des études de traduction postmodernes.
Ce document est protégé par la loi sur le droit d'auteur. L’utilisation des services d'Érudit (y compris la reproduction) est assujettie à sa politique d'utilisation que vous pouvez consulter en ligne.

https://apropos.erudit.org/fr/usagers/politique-dutilisation/ 


\title{
Nietzsche as precursor of postmodern translation studies
}

\author{
LIMING CHEN \\ Huaqiao University, Quanzhou, Chine \\ lemcheer@sina.com
}

\section{RÉSUMÉ}

En termes d'études postmodernes de traduction, le précurseur le plus reconnu est sans doute Friedrich Nietzsche (Erickson 2001 : 84), dont la pensée philosophique postmoderne se manifeste principalement sous ces formes: Antéchrist (rejet de tout attachement à Dieu), appel à une réévaluation de toutes les valeurs, négation de la métaphysique conventionnelle, insistance sur le perspectivisme, rejet de la rationalité des Lumières, valorisation de la volonté de puissance. La pensée philosophique de Nietzsche ainsi que ses réflexions sur la traduction jouent un rôle très important dans les études postmodernes de traduction, en détrônant l'auteur en tant que Dieu du texte, en libérant le traducteur et en ouvrant l'espace signifiant à la multi-potentialité interprétative. En même temps, ses idées visionnaires ont aidé les traducteurs à se délivrer de la remise en question éthique de leur re-créativité/réécriture, à les encourager à mettre en jeu leur subjectivité de traducteur et, partant, à élargir l'horizon des études en traduction. Les idées principales de Nietzsche, telles que le perspectivisme dans l'interprétation, la réévaluation des valeurs chrétiennes, le sens historique du passé et, notamment, la conquête des Anciens par la traduction, se sont réfractées aussi dans ses réflexions sur (les études de) la traduction. Bien qu'elles ne soient pas tellement systématiques, celles-ci ont ouvert la voie à une approche postmoderne en matière d'études de traduction et ont exercé une influence durable et profonde sur ses partisans, comme Heidegger, Gadamer, Benjamin, Pound, Derrida, Steiner, Lefebvre, Venuti, etc. Une investigation rétrospective sur les idées perspicaces de Nietzsche pourra sans doute nous aider à clarifier la filiation généalogique des études de traduction postmodernes.

\section{ABSTRACT}

Friedrich Nietzsche is generally considered the precursor of postmodern philosophy (Erickson 2001: 84), the basis of which are: Antichrist (rejection of all attachment to God) and a call for a re-evaluation of all values, a negation of conventional metaphysics, an insistence on perspectivism, a rejection of Enlightenment rationality and the advocation of will to power. Nietzsche's postmodern philosophy and his thought on translation play a fundamental role in postmodern translation studies, uncrowning the author as God of the text, liberating the translator, and enlarging the space of multi interpretative signifiers. Meanwhile, his insights have helped extricate translators from ethical questions about their re-creativity, encourage them to develop a translator's subjectivity and consequently broaden the horizon of translation studies. Such radical thoughts as perspectivism in interpretation, re-evaluation of Christian values, a historical sense of the past, and the conquest of the Ancient, especially by translation, can also be applied to his thoughts on translation (studies), though not so systematic as they are, initiating an inspiring postmodern approach to translation studies, and exerting a lasting and profound influence on his followers like Heidegger, Gadamer, Benjamin, Pound, Derrida, Steiner, Lefevere, Venuti, etc. An elaborative review of Nietzsche's insightful ideas as such should clarify the genealogy of postmodern translation studies in general. 


\section{RESUMEN}

A Friedrich Nietzsche se le considera el precursor de la filosofía posmoderna (Erickson 2001: 84) lo cual se manifiesta en la negación de Dios; esto da lugar a una reevaluación de todos los valores, a la negación de la metafísica convencional y la proposición del perspectivismo y deja a un lado la racionalidad de la comprensión y la afirmación de la voluntad del poder. La filosofía posmoderna de Nietzsche y su pensamiento sobre la traducción juegan un papel muy importante en los estudios de traducción posmodernos al destronar al autor como el dios del texto, liberando al traductor y ampliando el espacio de significantes multi-interpretativos. Sus ideas han sido de gran utilidad a la hora de liberar a los traductores de la necesidad ética de cuestionarse su capacidad para la creatividad / reescritura, impulsando no solo el desarrollo de la subjetividad traductológica sino también lo posible en los estudios de traducción. Estas ideas radicales, tales como el perspectivismo en la interpretación, la reevaluación de los valores cristianos, el sentido histórico del pasado y la conquista de lo Antiguo especialmente a través de la traducción, también aplicada a su pensamiento sobre la traducción (y los estudios de traducción), aunque no de forma tan sistemática han dado lugar a un acercamiento posmoderno a los estudios de traducción y han ejercido una profunda influencia sobre seguidores como Heidegger, Gadamer, Benjamin, Pound, Derrida, Steiner, Lefevere, Venuti, etc. Una nueva mirada a las trascendentes ideas de Nietzsche puede servir para clarificar la genealogía de los estudios de traducción posmodernos.

\section{MOTS-CLÉS/KEYWORDS/ PALABRAS CLAVE}

Nietzsche, philosophie postmoderne, études de traduction postmodernes, perspectivisme, précurseur

Nietzsche, postmodern philosophy, postmodern translation studies, perspectivism, precursor

Nietzsche, filosofía posmoderna, estudios de traducción posmodernos, perspectivismo, precursor

\section{Nietzsche's postmodern philosophy}

In addition to being a cultural critic, philologist, poet, composer, music critic, thinker, and "the last metaphysician of the West" (Heidegger 1939/1991: 8), Germanborn Nietzsche (1844-1900) is also considered the precursor of postmodern philosophy (Erickson 2001: 84; Robinson 2000: 33). His prolific works, with his insightful aphorisms and penetrating irony, challenge the objectivity of truth and the Western value system based on the Christian God. They have generated a profound and lasting impact on modern and contemporary existentialist and postmodern thinkers, such as Sigmund Freud, Karl Jaspers, Martin Heidegger, Jean-Paul Sartre, Roland Barthes, Jean-Francois Lyotard, Michel Foucault, Jacques Derrida, and Fredric Jameson.

His postmodernism is also found in his critical thinking on translation (studies) and has more or less benefited his followers, including Hans-Georg Gadamer, Walter Benjamin, Jacques Derrida, Paul de Man, George Steiner, Ezra Pound, Gayatri C. Spivak, André Lefevere, and Lawrence Venuti. As a precursor of postmodern translation studies, his ideas have certainly encouraged and compelled them to think differently about translation, as well to define and to re-evaluate it, as shall be illustrated below.

For Nietzsche, all the grand narratives of his time had collapsed. People's beliefs in reason and logic, science and its laws, truth and value were all without foundation. 
Faith in reason and progress, born during the Enlightenment, was no longer tenable and the only reliable truth was the will to power, which enthusiastically led him to call for a "revaluation of all values" (Nietzsche 1895/1954: 656). All of these thoughts are so postmodern in nature that he has often been acknowledged as the precursor of postmodernism. Habermas (1985/1987: 83) has also argued for "Nietzsche as a turning point" into postmodernity, for he "renounces a renewed revision of the concept of reason and bids farewell to the dialectic of enlightenment" (Habermas 1985/1987: 86). Complicated as Nietzsche's postmodern thoughts were, the main concepts can nevertheless be categorized as the negation and the critiquing of traditional metaphysics and Christianity, the affirmation and assertion of the will to power, and perspectivism.

To understand Nietzsche's thinking on postmodern translation studies, one needs to examine his postmodern philosophy. Indeed, his ideas on translation are but an extension and token of this postmodern philosophy, characterised by the following concepts: Antichrist (God) and a call for the revaluation of all values, the negation of older metaphysics, an insistence on perspectivism, a rejection of Enlightenment rationality, and the signification of will to power.

For Nietzsche, Christianity was the most pernicious stage in a peculiar way of thinking that began with Socrates. Throughout his writings, he never changed his criticism of Christianity. He used historical criticism to oppose Christianity, which was, for him, the true crisis of Western civilization, "a religion for which Nietzsche seems to have had a passionate Oedipal hatred" (Robinson 1999: 9). Later, with the maturing of his philosophy of the overman, he reaffirmed his sense of valuation of will to power and fought against Christianity, arguing that it "should not be beautified and embellished: it has waged deadly war against this higher type of man; it has placed all the basic instincts of this type under the ban" (Nietzsche 1895/1954: 571). To borrow his own words, Christianity is a "slave-morality" (Nietzsche 1886/1911: 231) that stands for a pernicious value system and impedes the promising evolution and the eventual production of a new and superior kind of human being.

Nietzsche believed that Christian morality encourages a belief in the repression of instinct and tends to thwart creative energies. All modern Western belief systems were founded on a whole series of fanciful beliefs and metaphysical assumptions that inevitably influenced all of Western philosophy, especially during the Enlightenment. Socrates believed in immortal souls and absolute truths. Plato, his disciple, created a "two-world" philosophy, claiming the daily material world to be an inferior copy of a perfect, transcendent one. Descartes "proved" the existence of immortal souls. Kant pronounced the existence of another superior, "noumenal" world that our human senses can never expect to reach. In this sense, they were all fascinated by the belief in the possibility and fantasies of both absolute knowledge and transcendent worlds, which is exactly what Nietzsche was determined to terminate or revaluated (Nietzsche 1895/1954: 656).

So, Nietzsche would discard the fanciful Christian belief, represented by God and modern moral philosophy, and declare the death of God: “'Whither is God?' he cried; 'I will tell you. We have killed him - you and I. All of us are his murderers"' (Nietzsche 1882/1974: 181; emphasis in original). Since God is dead, all the values based on God should inevitably be revaluated. This is explicitly expressed in the subtitle of Will to Power: Attempt at a Revaluation of All Values (Nietzsche 1901/1910). 
The aim of his severe criticism of Christian morality was to replace it with the values of a new overman.

For Nietzsche (1889/1954: 500), "Christianity is metaphysics of the hangman." Metaphysics, as in the belief in a "real" world beyond time, history, and nature, has thus reached its potential. The ultimate fate and downfall of metaphysics were proclaimed with the statement on the death of God (Nietzsche 1882/1974: 167; Nietzsche 1885/1923: 6). His idea of the collapse of metaphysics can be comprehended not only as the death of a "symbolic God" (the death of the very specific and particular God of Christianity that has held European humanity in bondage for two millennia), but also as the death of the God of theologians, philosophers, and some scientists. In other words, the "God" that serves as a guarantor of order, structure, and purpose in the universe at large (Pearson and Large 2006: xxxv). Actually, Nietzsche is not the first to proclaim such a death, for Hegel had previously expressed a similar idea (Hegel 1807/1998: 498), but it was not until Nietzsche that this subversive project achieved its logical conclusion.

Aligning with his attack on metaphysics is Nietzsche's promotion of perspectivism. He insists that there are no real things or facts, only interpretation: "No, facts[sic] is precisely what there is not, only interpretations. We cannot establish any fact 'in itself': perhaps it is folly to want to do such a thing" (Nietzsche 1901/1968: 267). For him, "[e]verything is subjective" (Nietzsche 1901/1968: 267). This implies that there is no way of seeing the world that can be taken for granted as definitively "true," but this does not necessarily entail that all perspectives are equally valid: "In so far as the word 'knowledge' has any meaning, the world is knowable; but it is interpretable otherwise, it has no meaning behind it, but countless meanings. - 'Perspectivism"' (Nietzsche 1901/1968: 267; emphasis in original).

Perspectivism plays a crucial role in Nietzsche's (postmodern) philosophy. It is "at the center of Nietzsche's thought. To have a perspective is to have horizons" (Strong 1985: 173). Thus, all ideations take place only from particular perspectives and there are many possible perspectives in which judgment of all truth or value can be made. Perspectivism thus rejects objective metaphysics, claiming that no evaluation of objectivity can transcend contextualized facts, cultural formation or subjective designations. Consequently, there should be no objective facts, nor any knowledge of a thing-in-itself. Truth is thus separated from any particular point, and so any ethical or epistemological absolutes disappear: "It is our needs that interpret the world; our drives and their For and Against. Every drive is a kind of lust to rule; each one has its perspective that it would like to compel all the other drives to accept as a norm" (Nietzsche 1901/1968: 267). This perspectivism rejects traditional metaphysics, claiming " $[\mathrm{m}]$ orality is merely an interpretation of certain phenomena - more precisely, a misinterpretation" (Nietzsche 1889/1954: 501). There would be no real world laid bare before us were we able to subtract our "interpretations."

In terms of Nietzsche's perspectivism, things can only be considered as they are if they are regarded in multiple and as multiple, instead of just being "understood as the perspective of something, for there can be nothing without perspective, which is not a perspective" (Strong 1985: 175). However, it does not refer to a sheer promotion of subjectivity as usually acknowledged in interpretation studies. In fact, Nietzsche advocates a dialectical middle ground between subjectivity and objectivity, arguing for "the apparent objective character of things: could it not be merely a difference of 
degree within the subjective?" (Nietzsche 1901/1968: 303) Accordingly, they can be considered to hold true only from some particular perspective within the context (Schacht 2002: 61), maintaining that upon closer examination they would reveal a difference of contextuality.

The Enlightenment in Europe proposed that everything in the world must stand to relentless judgment before the court of rational thought. When Descartes shifted the epistemological basis from external authority to internal certainty through his cogito ergo sum,

[e]nlightenment, understood in the widest sense as the advance of thought, has always aimed at liberating human beings from fear and installing them as masters. Yet the wholly enlightened earth radiates under the sign of disaster triumphant. (Horkheimer and Adorno 1947/2002: 1)

What Horkheimer and Adorno set out to elaborate is a certain ambivalence that has led to the pessimism about the possibility of human emancipation. Nevertheless, its pursuit of universal reason and the rejection of pluralities of thought cannot be neglected. Enlightenment becomes totalitarian, paradoxically, in that "the myths which fell victim to the Enlightenment were themselves its products" (Horkheimer and Adorno 1947/2002: 5).

As Hegel noted, the rational is a self-recognition of absolute spirit. He "conceived of reason as the reconciling self-knowledge of an absolute spirit" (Habermas 1985/1987: 84). Hegel tries to replace logicality with dialectics in the hope that enlightenment would return. Habermas also follows Hegel in viewing reason as a healing power for unification and reconciliation. However, it is not the Absolute that he bears in mind, but the unforced inter-subjectivity of rational agreement. Nietzsche is confronted with two alternatives: to submit subject-centered reason again to an immanent critique or to completely abandon the law of dialectic of enlightenment. Nietzsche does not follow Hegel's steps, but "renounces a renewed revision of the concept of reason and bids farewell to the dialectic of enlightenment" (Habermas 1985/1987: 86).

Nietzsche does not resort to another sense of reason to replace that of enlightenment, but bids a thorough farewell, abandons all hope for a dialectic of enlightenment. He "owes his concept of modernity, developed in terms of his theory of power, to an unmasking critique of reason that sets itself outside the horizon of reason" (Habermas 1985/1987: 96). He insisted that the world was embodied with the pastiche of imagination and interpretation without either aim or text, the power to create meaning forms being the authentic core of the will to power. This subject-centered reason owes its entire inventory to the occurrence of a masochistic inversion of the very core of the will to power: "The transsubjective will to power is manifested in the ebb and flow of an anonymous process of subjugation" (Habernas 1985/1987: 95). The will to power, for Nietzsche, is intuitive, spontaneous, and irrational, an intensified version of Schopenhauer's (1969: 275) will-to-live. It reframes the will-to-live within an irrational philosophy and replaces traditional metaphysics, represented by God. All in all, "[t]his world is the will to power - and nothing besides! And you yourselves are also this will to power - and nothing besides!" (Nietzsche 1901/1968: 550; emphasis in original). 


\section{Nietzsche' postmodern thinking on translation (studies)}

Nietzsche's postmodern philosophy is inevitably reflected in his thinking on translation in accordance with his philosophical research and has greatly influenced his followers, though not so systematically. His reflections on postmodern translation (studies) mainly refer to The Gay Science and Beyond Good and Evil, and his "Translations" in The Gay Science deserves most attention, which can be categorized into such aspects as 1) the death of God and the birth of the author; 2) conquering and absorbing out of will to power.

From the perspective of perspectivism, Nietzsche announces the death of God, who symbolizes the Western system of spiritual value. Those rational Christian values on which the Western system is based have collapsed and so the eternal truth loses its foundation, leading to the eventual death of the author as God of text. Real facts do not exist any longer; "facts[sic] is precisely what there is not, only interpretations. We cannot establish any fact 'in itself"” (Nietzsche 1901/1968: 267). The unicity of meaning of the textual world disappears and any meaning then becomes the result of some specific perspective and something of an invention, just as Nietzsche maintains that ' $\mathrm{t}]$ he 'subject' is not something given, it is something added and invented and projected behind what there is. ... it has no meaning behind it, but countless meaning" (Nietzsche 1901/1968: 267). Thus, the meaning of a text crosses its own limits from unicity to multiplicity, opening up an infinite wide scope of potential interpretation.

As such, for those poet-translators like Quintus Horace and Sextus Propertius of ancient Roman, the authors of Old Greek are all dead. The translator continues the poets' life, so the birth of the translator must come at the cost of the death of the author: "What was it to them that the real creator had experienced this and that and written the signs of it into his poem?" (Nietzsche 1882/1974: 137)

From ancient times onward, almost all ideas or principles about practices and theories of translation have focused on the original as their unique starting point and destination, which is most specifically manifested in the extensive and everlasting Bible translation, exegesis or interpretation. Whether for St. Jerome, St. Augustine of ancient times, Boethius, Wyle of the Middle Ages, or Erasmus, Luther of the Renaissance, Daniel Huet, Batteux, Schlegel, Goethe, Hölderlin, Dryden, Campbell, Tytler, Arnold of modern times, or Jakobson, Catford, Savory, Newmark, Nida, Fedorov of more contemporary times, their aspirations of equivalence to the original are almost undoubtedly the everlasting theme, although there were controversial ideas about translations as to whether they should be literal or free, accurate or smooth, reproductive or creative, now and then or here or there. In other words, the original (author) is the ultimate and ontological pursuit and convert, and enjoys the absolute authority which equals the holy authority of the Christian God. Nietzsche employs both Rome's occupation of Greek territory and Rome's cultural conquest metaphorically to resist and overthrow this authorial authority. Declaring the death of the original, he erases the marks of the original, makes the translation absorb and eventually replace the original, so as to obtain and manifest the Roman translators cultural identity in the target language.

In Nietzsche's view, a translator should give up archaeological source-tracing, should not be confined to past history, should get rid of any historical signs as well 
as substitute them with the present, and should live a historical life in the present. It is therefore argued that a translator should act according to a specific time, place, and readers, epistemologically, methodologically, and teleologically.

As poets, they had no sympathy for the antiquarian inquisitiveness that precedes the historical sense; as poets, they had no time for all those very personal things and names and whatever might be considered the costume and mask of a city, a coast, or a century: quickly, they replaced it with what was contemporary and Roman. (Nietzsche 1882/1974: 137)

For Nietzsche, "[t]he most strongly believed a priori 'truths' are for me - provisional assumptions" (Nietzsche 1901/1968: 273; emphasis in original). Truth is not convincing and even an error: "Truth is the kind of error without which a certain species of life could not live. The value for life is ultimately decisive" (Nietzsche 1901/1968: 272; emphasis in original). Truth is not a constitutional prescription and any epistemological idea, like equivalence or truth, is an illusion not to be grasped permanently. It is a "mental illness, an idiocy" (Nietzsche 1882/1974: 335) if we assume

the faith in a world that is supposed to have its equivalent and its measure in human thought and human valuations - a 'world of truth' that can be mastered completely and forever with the aid of our square little reason. (Nietzsche 1882/1974: 335)

The world is forever productive, and so "all their reason and all their evaluations and perspectives on things have to be brought into the light. So far, all that has given color to existence still lacks a history" (Nietzsche 1882/1974: 81).

The author, as the first interpreter, produces the text, which is then left where it was, as some historical trace, having gained its historical meaning. However, over time and space, the text has to die, become useless due to the loss of its historic meaning. It can then reacquire present meaning. In this way, the original author (text) has to inevitably die for the suitable translator, who would re-inject soul into it, to rejuvenate it, and to continue its afterlife in terms of "Being-towards-death" (Heidegger 1927/2001: 281). The birth of the translator/translation must come at the cost of the death of the author/ original, so Nietzsche would ask, like in the voice of such translators as Horace was of ancient Greece: "Should we not make new for ourselves what is old and find ourselves in it? Should we not have the right to breathe our own soul into this dead body? For it is dead after all; how ugly is everything dead!" (Nietzsche 1882/1974: 137) Having killed the God who embodies humanity's ultimate value, Nietzsche has also killed the author as God of text, by overthrowing the author's authenticity, liberating the text and translator, thus enabling the author to be regenerated like the rise of the Phoenix from the ashes, establishing its present significance.

The concern for history tends to serve the present rather than to only reproduce the past. Nietzsche puts a special focus on historical meaning and he values its present significance in terms of how we translate and how we make the past serve the present: "The degree of the historical sense of any age may be inferred from the manner in which this age makes translations and tries to absorb former ages and books" (Nietzsche 1882/1974: 136-137). What Nietzsche intends is not to go back to the past, nor to be confined to the old traces or to reproduce history, but to reflect on and take advantage of history and make it serve the present, because history only exists in the present and "every true history is contemporary history" (Croce 1915/1921: 12). 
There is no doubt that Nietzsche continues to insist on productivity, interpretativeness, and illusion. For him, "the value of the world lies in our interpretation" and the world "is 'in flux,' as something in a state of becoming, as a falsehood always changing but never getting near the truth: for - there is no 'truth"” (Nietzsche 1901/1968: 330). History is also the gain of interpretation and can only obtain its meaning through human interpretation by participating in contemporary life. It is only through this means that history and classics can live in the present world, be renewed and refresh their past glory. Such ideas can be verified in what Nietzsche thinks about Ancient Rome's translation and exploitation of Greek cultural heritage:

$[\mathrm{H}]$ ow forcibly and at the same time how naively it took hold of everything good and lofty of Greek antiquity, which was more ancient! How they translated things into the Roman present! How deliberately and recklessly they brushed the dust off the wings of the butterfly that is called moment! (Nietzsche 1882/1974: 137)

Whether history has meaning just depends on how we can make it serve the present. It has no definite given truth and can only obtain its meaning through the present act of interpretation. It is only when a translator can courageously brush the dust off the wings of the butterfly as a historical specimen and translate into it some of the soul of the present moment that the butterfly can become a born-again creation, regain its ancient glory and flutter its way around the garden of the present: "Should we not make new for ourselves what is old and find ourselves in it? Should we not have the right to breathe our own soul into this dead body?" (Nietzsche 1901/1974: 137). Here, Nietzsche shows his practical, pragmatic reason by abandoning the static sense of history, arguing, "[c]onsciousness is present only to the extent that consciousness is useful. It cannot be doubted that all sense perceptions are permeated with value judgments" (Nietzsche 1901/1968: 275; emphasis in original).

Since the sense of history represents and serves the present, it seems unnecessary for a translator to indulge in it. It is when those old and alien things get rid of the retro, exotic coat of history, and disenchant its history, that history will live in the moment, avoiding its embarrassment with the present: "They did not know the delights of the historical sense; what was past and alien was an embarrassment for them" (Nietzsche 1882/1974: 137). To brush "the dust off the wings of the butterfly that is called moment" (Nietzsche 1882/1974: 137), a translator has to use his will to power to usurp what is needed, just as the Romans courageously and recklessly seized what was Greek and transformed it into Roman, thus Romanizing it:

[B]eing Romans, they saw it as an incentive for a Roman conquest. Indeed, translation was a form of conquest. Not only did one omit what was historical; one also added allusions to the present and, above all, struck out the name of the poet and replaced it with one's own-not with any sense of theft but with the very best conscience of the imperium Romanum. (Nietzsche 1882/1974: 137-138)

According to Nietzsche (1901/1968: 218), to refresh antiquity and to let it serve the present, a translator should take the "[r] estoration of nature: moraline-free" view and regard "[m] orality [as] a useful error." Seemingly immoral, this idea is real morality and is realized only through the strong motivation of will to power: "[S]upreme values hitherto are a special case of the will to power; morality itself is a special case of immorality" (Nietzsche 1901/1968: 217). 
The will to power and conquest, as its externalization, play a very important role in Nietzsche's philosophy of will, serving as a prerequisite and inevitable result, which is frequently expressed, but not confined to his thinking on translation, such as: "All meaning is will to power (all relative meaning resolves itself into it)" (Nietzsche 1901/1968: 323). It is viewed as deconstruction, reconstruction, and transformation. In this way,

The will to power can manifest itself only against resistances. [...] Appropriation and assimilation are above all a desire to overwhelm, a forming, shaping and reshaping, until at length that which has been overwhelmed has entirely gone over into the power domain of the aggressor and has increased the same. (Nietzsche 1901/1968: 346)

It shows that Nietzsche's theory of will to power has its consistency and continuity in trans-subjectivity. This is also applied to his thinking on translation. Nietzsche's proposition for (translator's) subject and subjectivity is almost without reservation, which completely extricates him from any blame for a translator's unfaithfulness and immorality. To gain its contemporary meaning is the greatest morality. Only translators like Horace in Ancient Rome, equipped with the strong will to power, can make the original text survive time and "Being-towards-death," starting its afterlife, making the past serve the present, the foreign becoming ever more the domestic. It is the Ancient Roman Empire that rejuvenated Ancient Greek traditions and embodied the best noble conscience that surpasses history by means of such transformation of powerful conquest as translation.

Nietzsche's advocation of perspectivism and plurality of interpretation is related to, though not so closely shown in, his discussion of translation, since translation by nature is a kind of interpretation and also an ongoing dialogue between the author and reader through the text in a specific time and place. Faithfulness in translation is not only confined to loyalty to the original text (and its author), but contributes to the present cultural construction through certain perspectives and practices so as to do and complete things with translation. This suggests that any thinking or interpretation originates from a particular perspective, and any judgment of truth or value is the outcome of the various conceptual schemes, without definite "truth":

What therefore is truth? A mobile army of metaphors, metonymies, anthropomorphisms; in short a sum of human relations which became poetically and rhetorically intensified, metamorphosed, adorned, and after long usage seem to a nation fixed, canonic and binding; truths are illusions of which one has forgotten that they are illusions; worn-out metaphors which have become powerless to affect the senses; coins which have their obverse effaced and now are no longer of account as coins but merely as metal. (Nietzsche 1896/1911: 180)

For Nietzsche, the truths that are based on the Christian God are all but illusions and subjective metaphors; meaning is not static and has to be (re)interpreted according to the requirements of the time. So he insists on believing himself and subjectivity, in other words, "Everything is subjective" (Nietzsche 1901/1968: 267). This subjectivity is not given as an a priori, but rather some contemporary interpretable outcome. That is to say that " $[\mathrm{t}]$ he world is knowable; but it is interpretable otherwise, it has no meaning behind it, but countless meaning [...] It is our needs that interpret the world" (Nietzsche 1901/1968: 267; emphasis in original). People usually (re)locate history in terms of present needs; this also can be applied to translation. For 
Nietzsche, translation can decide how high a degree an age can reach: "The degree of the historical sense of any age may be inferred from the manner in which this age makes translations and tries to absorb former ages and books" (Nietzsche 1882/1974: 136-137; emphasis in original). The historical sense lies in how we interpret and understand history in various ways, which accounts for the homogeneity between the historical sense of translation and the perspectivism of interpretation. This has inspired Heidegger, Gadamer, and Foucault, with Foucault maintaining that " $\mathrm{t}]$ here is nothing absolutely primary to interpret, for after all everything is already interpretation, each sign is in itself not the thing that offers itself to interpretation but an interpretation of other signs" (Foucault 1967/1998: 275). For Foucault, interpretation is both the premise and outcome of interpretation.

Nietzsche manages to dethrone the ultimate authority of God and monologism of value, overthrow reason and slavery morality, bid farewell to traditional metaphysics. In their places, he proposes pluralism, perspectivism, revaluation of value and he focuses on the historical sense of the present while advocating will to power and its sense of truth of conquest. Much of his postmodern philosophical thought is most clearly manifested in his idea about translation (studies).

\section{Nietzsche's influence on later postmodern translation studies}

Nietzsche's postmodern thinking on translation, more or less, overtly or covertly, has influenced or inspired a number of modern thinkers or theorists such as Heidegger, Gadamer, Steiner, Benjamin, and especially Derrida, as well as translation theorists and scholars like Pound, Lefevere, and Venuti, who not only are translators themselves but have also greatly influenced practical translation scholars and translators.

\subsection{Influence on modern thinkers}

Just like Nietzsche, Heidegger also questions and criticizes the entirety of Western metaphysics and advocates for his interpretative philosophy of "the Being of the entities" (Heidegger 1927/2001: 26). In his Was heißt Denken? (Heidegger 1954) and The Anaximander Fragment (Heidegger 1950/1984), he opposes literal translation and proposes übersetzen of meaning to enter into the essence of language. In the very beginning of The Anaximander Fragment, after comparing Nietzsche's and Diels' translation, he states, "when a translation is only literal it is not necessarily faithful. It is faithful only when its terms are words which speak from the language of the matter itself" (Heidegger 1950/1984: 14). Such übersetzen or translation is a kind of leap over a gap of a long history, and

[t]his requires that we translate what is said in Greek into our German tongue. To that end, our thinking must first, before translating, be translated to what is said in Greek. Thoughtful translation to what comes to speech in this fragment is a leap over an abyss [Graben]. The abyss does not consist merely of the chronological or historical distance of two-and-a-half millennia. (Heidegger 1950/1984: 19)

For Heidegger, only in the dialogue across a historical gap can the old Anaximander be translated: "Only in thoughtful dialogue with what it says can this fragment of thinking be translated" (Heidegger 1950/1984: 19). Translation in this way is the 
everlasting dialogical interpretation of thought over history. "All interpretations of Greek philosophy themselves already rest on this translation" (Heidegger 1950/1984: 23). He insists that every translation is interpretation and all interpretation is but translation (Gondek 1997: 269). There is no interpretation without translation, and no translation without interpretation. Such "authentic interpretation always requires doing 'violence' to the texts" (Guignon 1993: 3). For Heidegger, "Thinking of Being is the original way of poetizing [...] Because it poetizes as it thinks, the translation which wishes to let the oldest fragment of thinking itself speak necessarily appears violent" (Heidegger 1950/1984: 19), and thus "the poet/translator is able to translate/ transport himself to that original culture" (Gentzler 2001: 156). It sounds much the echo of Nietzsche's idea of the translation of Greek antiquity as "a form of conquest" (Nietzsche 1882/1974: 137), replacing, and forcing.

In Gadamer's view, translation means understanding, which is sure to surpass the author's horizon: "Nowhere does understanding mean the mere recovery of what the author 'meant,' whether he was the creator of a work of art, the doer of a deed, the writer of a law book, or anything else" (Gadamer 1967/1976: 210). Translation is far more than merely repeating the original, it requires the entry of the translator's subjectivity, which is also not the task of a translator: "The task of the translator, therefore, must never be to copy what is said (i.e., in its meaning) in order to carry over what is to be said into the direction of his own saying" (Gadamer 1967/1976: 68). To look for the author is futile because the author is dead at the moment the text is born: "The norm for understanding a book is not the author's meaning" (Gamader 1960/2004: 184). The author's intentional fallacy has already been revealed, the translator as an interpreter should put the meaning to be understood in the text where another speaker lives. The original is not considered to be the ultimate pursuit, but the fusion of different horizons.

In line with Heidegger's argument, Gadamer emphasizes that all translation is interpretation or understanding, and the meaning of a text must have its refreshed role: "[S]ince it must be understood within a new language world, it must establish its validity within it in a new way. Thus every translation is at the same time an interpretation" (Gadamer 1960/2004: 386). In this way, understanding is, per se, a kind of negotiation or translation in which the meaning of the past is replaced in the present context, revivifying and reconstructing the historicity of "Dasein in terms of temporality" (Heidegger 1927/2001: 63).

Both Heidegger and Gadamer insist on the "historical recontextualizing" of the original (Gentzler 2004: 156). Their ontological thoughts about the historicity and contemporariness of translation, universality, and infinity are closely related to Nietzsche's opposition to the absolute ontological priority of text and his concern for the historical sense of the present and perspective interpretation.

Foucault's discussions on power and discourse are very inspiring since no human relationship is devoid of power, including the relationship between the author and the reader. Those Enlightenment principles are just what he attempts to argue against. He reiterates the question: "What difference does it make who is speaking?" (Foucault 1969/1998: 205-222). He discards the author's subjectivity as a foundational structure or premise of reading, but sees it rather as the result of critical reading, so as to question and deny the author's ultimate authority. This is basically what Barthes elaborates about textual theory: "[T] he work is a fragment of substance, occupying a part of the 
space of books," whereas "the Text is not the decomposition of the work, it is the work that is the imaginary tail of the Text; or again, the Text is experienced only in an activity of production" (Barthes 1967/1977: 156-157; emphasis in original). Such deconstructive actions of these French poststructuralists as questioning the logos, subversion of the author's power and even the killing of the author bear great similarity with their precursor Nietzsche's postmodern philosophy. Since God is dead, the author as God of the text must also die so that the space for creative reading and writing could be enlarged, the signifier could be increased and the birth of the reader could be realized. In a word, "the birth of the reader must be at the cost of the death of the Author" (Barthes 1967/1977: 148).

However, among the most inspired are Walter Benjamin and Jacques Derrida. The former examines translation "at the deepest level of linguistic theory" (Benjamin 1916/1997: 69), and maintains that "[t]ranslation is removal from one language into another through a continuum of transformations" (Benjamin 1916/1997: 70). His concept of translation thus moves to the center of his ontological reflections on the multiplicity of human languages and the philosophy of language. As a process of turning "the nameless into name" (Benjamin 1916/1997: 70), translation of the language of things into that of man is therefore "the translation of an imperfect language into a more perfect one, and cannot but add something to it" (Benjamin 1916/1997: 70). So that is "precisely in relation to the activity of naming that Benjamin employs the word 'translation.' Naming is a type of translation" (A. Benjamin 1989: 94), hence a transformation and reconstitution. Its nature does not lie in communication or information. In this way, translation no longer aims to obtain accurate similarity to the original, rather, it is a creative transformation that (re)names to enrich the evolved languages. To de-center/demystify the original authority and to pursue difference rather than likeness between the original and the translation are what Benjamin shares with Nietzsche, better expressed in his definite claim that "no translation would be possible if in its ultimate essence it strove for likeness to the original" (Benjamin 1923/1968: 70).

Benjamin is as compelling and insightful as he is when dealing with such weightier issues as the philosophy of language and epistemology. For him, language bears a close relationship to translation and even inheres in translation: "every evolved language (with the exception of the word of God) can be considered a translation of all the others" (1916/1997: 70). If Nietzsche redefined translation as a kind of conquest, absorbing, and replacement with his will to power, Benjamin did so by entering into the essence of language grown in translation, claiming that "even the greatest translation is destined to become part of the growth of its own language and eventually to be absorbed by its renewal" (1923/1968: 73), which is also true of the Adamic process of naming things, a cognitive action (behavior of cognition).

In terms of his acclaimed The Task of the Translator, Benjamin reiterates his opposition to reproductive translation, declaring that "no translation would be possible if in its ultimate essence it strove for likeness to the original" (Benjamin 1923/1968: 73). Only by bringing forth the new through the old can the original survive, for "the life of the originals attains in them to its ever-renewed latest and most abundant flowering" (Benjamin 1923/1968: 72). Consequently, he proposes a kind of liberation and refreshed recreation to obtain a kind of ideal "pure language" (Benjamin 1923/1968: 74). To realize it, the task of the translator is thus "to 
release in his own language that pure language which is under the spell of another, to liberate the language imprisoned in a work in his re-creation of that work" (Benjamin 1923/1968: 80), rather than to try to copy the original, for "[t]ranslation is so far removed from being the sterile equation of two dead languages" (Benjamin 1923/1968: 73). Such being the case, translation is never "the retrieval of the past, but rather a futural projection" (A. Benjamin 1989: 98), intimately related to the "afterlife" (Benjamin 1923/1968: 71) of the text. As "a transformation and a renewal of something living" (Benjamin 1923/1968: 73), translation ensures the survival and the afterlife of the original, and hence the translator's task is to integrate "many tongues into one true language" and to validate "ripening the seed of pure language in a translation" (Benjamin 1923/1968: 77).

Like Nietzsche, Benjamin also argues for naming as translation, while the former focuses more on its temporal replacement, the latter focuses more on the spatial displacement. For Benjamin, just as every language can be viewed as "a translation of all the others" (Benjamin 1916/1997: 71), the original language is always a displaced language, "not displaced from a home it once occupied but more significantly its mode of being is displacement" (A. Benjamin 1989: 100). Just as de Man points out that, in Benjamin, there persists such a movement "of a constant displacement, of a constant exile, of a constant alienation in a sense" (de Man 1986/2002: 103). That historical act is also very close to Nietzsche, albeit with an epistemological difference. Indeed, Nietzsche pays more attention to active characteristics of intervening interpretation by means of the will to power, while Benjamin lays more emphasis on a mysterious messianic thinking of the essence of language and translation. It is clear that Benjamin "refers repeatedly to Nietzsche's critique throughout his methodological comments" (Cohen 2004: 207).

Derrida is another important thinker who has benefited a lot from Nietzsche. It is widely acknowledged that Derrida's elaboration of deconstruction is inextricably bound up with Nietzsche's inspiring writings (Royle 2003: 25) and "Nietzsche's 'suspicion of the value of truth [...] of meaning and of being, of «meaning of being' [...] is intimately shared by Derrida" (Spivak 1997: xxii). Derrida not only follows Nietzsche in discarding translation as reproducing the original, but carries it forward much further via challenging any definition of translation as transporting, representing or communicating the original "meaning" at all. He suggests that translation can be viewed as some incapable "play of the traces" or "a trace of the effacement of a trace" (Derrida 1967/1973: 156), where language is always seen in the process of modifying the original text, of deferring and displacing continuously any possibility of capturing that which the original desired to name.

Especially in Des tours de Babel (1985/2007), Derrida elucidates the necessity and the impossibility of translation, critiquing Walter Benjamin's The Task of the Translator, calling into question his idea that the translation of sacred texts is not always about communication with the receptor. He assumes translation to be a commitment, a duty, a debt, and a responsibility (Derrida 1985/2007: 220). The attitudes toward the original show the similarities and differences between Nietzsche, Benjamin, and Derrida. Advocating a functional intervening and exploiting of the translated, Nietzsche believes that the original (Greek classics) is something that is to be conquered, captured, renamed, and appropriated freely by the subject, thus decentering the original (author's) authority. Benjamin and Derrida, however, focus 
more on the affinities and complementation of the original and the translation, while at the same time destructuring the original authority.

What Nietzsche adopts in translating may be called an aggressive active voice, whereas Derrida prefers a more middle voice, illustrated in his neologism différance: "to differ as discernibility, distinction, separation, diastem, spacing; and to defer as detour, relay, reserve, temporization" (Derrida 1972/1982: 18; emphasis in original), thus calling into question any ontological approach that attempts to determine an idea of Heideggerian "being" based on presence. Firstly, relating to deferral, it is the notion that words and signs can never fully summon forth what they mean, but can only be defined through appeal to additional words, where they differ. Thus, meaning is forever "deferred" or postponed through an endless chain of signifiers, forever floating in the air without any direction or center, never graspable or understandable, making it impossible for us to effectively communicate or have a dialogue. Secondly, relating to difference, it reveals the force that differentiates elements from one another and, in doing so, engenders binary oppositions (for example, foreignization vs. domestication, globalization vs. localization, [re]writing vs. translation, interpretation vs. reproduction, prescription vs. description, logo-centrism vs. colonization vs. decolonization, etc.) and hierarchies that underpin meaning itself, resulting in greater, possible discontinuities between different languages and cultures.

For Derrida, Benjamin explains the differences between meaning, original, and translation by means of organic metaphors: seeds and maturation, fruit, grain, kernel, and skin. Translation neither reproduces nor copies an original, but gives nourishment to the original and watches it grow and ripen. The pure language, the original, as a seed in language, can be fully grown when translated.

Derrida views translation as an ontological approach to philosophy, maintaining "[t]he origin of philosophy is translation or the thesis of translatability" (Derrida 1982/1985: 120). He illustrates in a deconstructive way his unique thinking on the possibility of translation, by asking "how is a text written in several languages at a time to be translated?" (Derrida 1985/2007: 201). In terms of the proper name, with its "irreducible multiplicity of tongues" (Derrida 1985/2007: 191), Babel, by confusion, could be translated by confusion and, as a proper name,

should remain untranslatable, but, by a kind of associative confusion that a unique tongue rendered possible, one could have thought to translate it, in that very tongue, by a common noun signifying what we translate as confusion. (Derrida 1985/2007: 192).

In other words, the translated text becomes a translation of another earlier translation, with the chain of signification infinitely regressing. The translation is no longer a reflection, a mirroring of the original, and neither is the language of the translation a reflection of the language of the original text. Thus, Derrida erases the traditional difference between the original and the translation, challenging "a strict boundary between the original and the version" (Derrida 1985/2007: 217). Nietzsche deconstructs the original with the will to power by advising us "to forget and destroy the text, but to forget and destroy it through action" (Derrida 1982/1985: 26); Derrida sees in Nietzsche possibilities for thinking otherwise about the nature of writing/ translation, characteristic of a deconstructive intervention or "entire thematics of active interpretation" (Derrida 1967/1973: 149) and views translation as always deferring and differing, at the same time erasing itself in the act of disclosure and 
interconnections. This can echo, but goes beyond Nietzsche by arguing that this loving of translation "does not reproduce, does not restitute, does not represent; essentially, it does not render the meaning of the original except at that point of contact or caress" (Derrida 1985/2007: 212).

Then, de Man continues this way of thinking and even goes further, declaring that " $[\mathrm{t}]$ he translator has to give up in relation to the task of refinding what was there in the original" (de Man 1986/2002: 80). Steiner offers four hermeneutic motions, namely trust, penetration, embodiment, and restitution, which are believed "to overcome the sterile triadic model which has dominated the history and theory of the subject" (Steiner 1975/1998: 319).

\subsection{Influence on translation theorists}

Besides the above-mentioned theorists in translation studies, there are also such translator-theorists as Ezra Pound, André Lefevere, and Lawrence Venuti who, based on Nietzsche's postmodern thought, have put forth their own insightful ideas that are significantly applied to their translation practice, shedding light on further translation practices and analysis.

For instance, in Pound's view, a translator's task is never to acquire merely a philological equivalence between the source language (SL) and target language (TL), but "to bring a dead man to life, to present a living figure" (Pound 1951: 211), which corresponds closely to Nietzsche's (1882/1974: 137) idea "to breathe our own soul into this dead body" to ensure its afterlife. Though Ezra Pound only referred to Nietzsche occasionally (Pound 1929/1954: 32; 1973: 391), he liked to frequently use a Nietzschean idea of power, which can be seen in his "interpretative translation" (Pound 1934/1954: 200; 1929/2000: 33) and in his "translation among the adaptations"1 to serve the present. These principles were integrated in the construction of his translational poetics, which he applied in his translations of Western and Eastern poems. This was namely the case in his (re)translating or rewriting of Japanese haiku-like poems (Pound 1914), his intentional lyricizing of Chinese classics (Dembo 1963: 48), as well as his famous appropriation of Chinese poetry in Cathay (1915). ${ }^{2}$ Many others (Chilton and Gilbertson 1990; Miner 1966) followed in his footsteps. Eliot (1934: xiv) points out that when talking about Pound's assimilation and paraphrase beyond translation, "good translation like this is not merely translation, for the translator is giving the original through himself, and finding himself through the original." Perhaps only in this postmodern way could Eliot (1934: xvi) say that "Pound is the inventor of Chinese poetry for our time." In his The Cantos, Pound employed such rich multilingual postmodern discourses and strategies as translational collages and allusions to express his thinking of history, politics, space, art, etc., that Preda (2001: 117) understands "The Cantos as collage." Consequently, his poems are so embedded with multilingual translations that it is hard to distinguish between his translational adaption or collage and his original writing. It is thus admitted that "Pound's poetics is essentially a poetics of translation and he has largely redefined the nature and ideal of poetic translation for the twentieth century" (Xie 1999: 204). It is just this innovative "translation among the adaptations," characteristic of the power of translator's subjectivity, that makes Pound's thought on translation defined as "a postmodern poetics of translation" (Preda 2001: 65). 
Dissatisfied with the narrow and mechanical linguistic approach to traditional translation study, which mainly involves "painstaking comparisons between originals and translations” (Munday 2001: 127), Lefevere argued strongly for translation as rewriting, which is also political, cultural manipulation:

Translation is, of course, a rewriting of an original text. All rewritings, whatever their intention, reflect a certain ideology and a poetics and as such manipulate literature to function in a given society in a given way. Rewriting is manipulation, undertaken in the service of power, and in its positive aspect can help in the evolution of a literature and a society. Rewritings can introduce new concepts, new genres, new devices and the history of translation is the history also of literary innovation, of the shaping power of one culture upon another. (Lefevere 1992a: vii)

That is to say, translation studied on the purely micro linguistic level has not been able to describe or deal with the text in its macro-cultural context and factors. Rather, "[t]ranslation has to do with authority and legitimacy and, ultimately, with power"; and it acts as a channel "through which foreign influences can penetrate the native culture, challenge it, and even contribute to subverting it" (Lefevere 1992b: 2).

Lefevere's socio-cultural approach to translation (studies) is mostly illustrated in the three different books: 1) Translation, Rewriting and the Manipulation of Literary Fame (Lefevere 1992a); 2) Translation/History/Culture (Lefevere 1992b): 3) Translating Literature (Lefevere 1992c). The first monograph is deployed with insightful case-studies, the second is a historical reader while the third is a practical coursebook. The view among the key elements is that "translation is the most obviously recognizable type of rewriting" (Lefevere 1992a: 9), including not just the traditional adaption, imitation, summary, but also editing, anthologizing, historiography, criticism and the like. These operative concepts constitute forms of mediation and manipulate the 'image' of a literary work for particular receptors in a specific society. So those engaged in the study of the evolution of literature by means of translation "have to ask themselves who rewrites, why, under what circumstances, for which audience" (Lefevere 1992a: 7) since translation

is potentially the most influential because it is able to project the image of an author and/or a (series of) work(s) in another culture, lifting that author and/or those works beyond the boundaries of their culture of origin. (Lefevere 1992a: 9)

The translators, as rewriters, "adapt, manipulate the originals they work with to some extent, usually to make them fit in with the dominant, or one of dominant ideological and poetological currents of their time" (Lefevere 1992a: 8), under such political and socio-cultural factors or constraints as power, patronage, ideology, and poetics.

Obviously, Lefevere aims to find a new conceptual framework for the study of literature and translation, and argues for "a descriptive, target-oriented, polysystembased approach" (Hermans 1994: 138). As a cultural turn in translation studies, his approach naturally draws much from reception theory and puts emphasis on the translator's role and power to give life, maintaining that "the impact of a translated work of literature depends not just on the image of it created by critics, but primarily on the image of it created by translators" (Lefevere 1995: 9) and that "[t]he important point Pound and Benjamin make is that of the translator as giver of life. This endows the translator with a certain power: texts that are not translated do not live on" (Lefevere 1995: 8). Such ideas as manipulation and rewriting by means of power are, 
nevertheless, consonant with the postmodernism of Nietzsche as well as of Pound and Benjamin, except that Lefevere elaborates and illustrates them more specifically in terms of their socio-cultural, political, ideological, and poetological inter-context or symbiotic system.

Lefevere's postmodern approach indicates a cultural turn in translation studies, one shared by Lawrence Venuti who has managed, either in theory or in practice, to reconstruct a history of foreignization (vs. domestication) translation (studies) and "an ethics of difference" (Venuti 1998: 82) by rethinking cultural "discourse, subjectivity, ideology" (Venuti 1992: title) in translation to ensure the translator's visibility (vs. invisibility) (Venuti 1995).

Venuti's monograph The Translator's Invisibility, clearly shows his reassessment of the Western history of fluent, domesticated translation in a Nietzschean and Foucaultian genealogical way. In keeping with it being a "cultural history with a professed political agenda" (Venuti 1995: 39),

it follows the genealogical method developed by Nietzsche and Foucault and abandons the two principles that govern much conventional historiography: teleology and objectivity. Genealogy is a form of historical representation that depicts, not a continuous progression from a unified origin, an inevitable development in which the past fixes the meaning of the present, but a discontinuous succession of division and hierarchy, domination and exclusion, which destabilize the seeming unity of the present by constituting a past with plural, heterogeneous meanings. (Venuti 1995: 39)

Apparently, Venuti's genealogy of knowledge refuses the conventional teleology and objectivity, reduces the translator's invisibility, but champions his or her visibility in a discontinuous succession of a destabilized past with plurality and heterogeneity, which clearly corresponds to Nietzsche's perspectivism.

What Venuti advocates is a symptomatic reading which, not essentially judgmental, requires readers to abandon the illusion of transparency concealed by the fluency of the translated literature. Its aim “is not to assess the 'freedom' or 'fidelity' of a translation, but rather to uncover the canons of accuracy by which it is produced and judged" (Venuti 1995: 37) so as to dethrone the canonized invisible domesticated translations. Such a "symptomatic reading can thus be useful in demystifying the illusion of transparency in a contemporary English-language translation" (Venuti 1995: 29). He believes that foreignizing translation is democratic and a kind of decolonization, in that it challenges imperialism and bourgeois consensus, claiming that "[f]oreignizing translation in English can be a form of resistance against ethnocentrism and racism, cultural narcissism and imperialism, in the interests of democratic geopolitical relations" (Venuti 1995: 20).

Venuti shows his clear awareness of the hegemony of fluent translating and its canonization of English-language translation from the seventeenth century onward, and decided to revise such a history and reconstruct it, maintaining that

the origins of fluent translating lie in various kinds of cultural domination and exclusion, but also that translation can serve a more democratic agenda in which excluded theories and practices are recovered and the prevailing fluency is revised. (Venuti 1995: 40)

He elaborates respectively and repeatedly his genealogy aims "to trace the rise of fluency as a canon of English language translation, showing how it achieved canonical status [...], and reconsidering the cultural and social values that it excludes at 
home" (Venuti 1995: 43). More specifically, his "genealogy reconstructs a foreignizing translation tradition [...] examines the specific cultural situations in which this tradition took shape, and evaluates its usefulness in combating domesticating translation in the present" (Venuti 1995: 100). Venuti's “democratic agenda" (Venuti 1995: 40) chiefly aims for a reconstruction of a history of foreignizing translation with its ethics of difference (Venuti 1998) and a revaluation of the traditional value of domesticating translation, all realized by means of violent interventions and "enormous power in the construction of national identities for foreign cultures" (Venuti 1995: 19). They are very consonant with Nietzsche's postmodern thought of "revaluation of all values" and will to power applied in his translation theory, with the exception of Venuti's more specific "espousal of (post)modernism, poststructuralism, postcolonialism, and feminism" (France 1996: 115) in a larger socio-cultural context.

Interesting enough, Pound, Lefevere, and Venuti have not only reported their insightful postmodern reflections on translation (studies) epistemologically, but applied them methodologically to active practices. Many of Pound's (translated) works (including The Cantos) have best exemplified this interaction of his (post) modern writing and translation among adaptation, which has also benefited Amy Lowell, William Carlos Williams, Gary Snyder, Steiner, Venuti, etc. Lefevere also concentrates on practice and his rewriting strategies underlying the strategies behind the (translated) texts provide particularly striking examples of the interaction, especially in his textbook Translating Literature (1992), particularly the transformations enhanced by cultural differences between the SL and TL, thus making Benjamin and Nietzsche the source of postmodernist/ deconstructionist translation theory. Venuti insists on (his) visible translations, with rich case studies, especially in Translation Changes Everything (2013), that resist fluency and highlight the foreignness and difference of the text to reconstruct national identities, paying necessary attention to norms involving "domestic values, beliefs, and social representations that carry ideological force in serving the interests of specific groups" (Venuti 1997: 362). In his introduction to Derrida's What Is a "Relevant" Translation, Venuti (2001) offers an interesting case analysis of the translation of Shakespeare's Shylock contract, maintaining that "[i]t is this unexpected [free 'merciful'] Christian rendering of the letter that compels the Jew to submit to the translation of the hegemonic discourse, Christianity itself" (Venuti 2001: 172). Thus, readers can see that "such strategies, while preserving the foreignness of foreign texts, were intended to construct a homogeneous cultural identity at home" (Venuti 2001: 172). There appears to be a positive interaction between translation theory and its application in practice.

\section{Conclusion}

The philosophical and cultural turn was a big event in translation studies. The discipline was no longer confined to the prevalent, linguistics-based theoretical approach, which tended to put forward an empirical science of translation. From then on, it also embraced a philosophical orientation that attracted the attention of the likes of Quine (1960, 1969, 1987, 1992), Davidson (1974, 1985/1996), Searle (1987/1996), Ricoeur (2006), etc. This new orientation aimed to offer an ontological and epistemological interpretation of translation studies, which in turn led to a culture-based orientation. The latter describes and emphasizes the cultural and political factors and 
values implicit in the practice and study of translation. In philosophy-based translation studies, Nietzsche's influence is no doubt enormous.

Indeed, as we have shown, postmodern translation studies can and should be viewed through the lens of Nietzsche philosophy. It is true of Heidegger and Gadamer's insistence that translation is an interpretation rather than a copy or the historical recontextualizing of the original. It is true of Benjamin's affirmation of a translation's "afterlife" and its potential to reach "pure language." It is true of Derrida's indeterminable différance of meaning inference and his question "What is a 'relevant' translation?" (Derrida 1999/2001) or of translatability in terms of the origin of philosophy. It is true of Pound's call for, and application of, life-giving "interpretative translation," of his "translation among the adaptations," and of his appraisal of writing as a "trans- or mistrans-lation" (Pound 1929/1954: 34). It is true of Lefevere's (1992a) principle of manipulation as rewriting in a specific cultural context, but also of Venuti's advocacy and practice of foreignization as a means of "cultural resistance" (Venuti 1995: 309). Thus, in the work of all these scholars one can see manifestations of Nietzsche's will to power, expressed in various ways, explicitly or implicitly, in accordance to Heidegger's (1927/2001: 26) belief of “the Being of the entities" in Nietzsche's philosophy. All can inevitably be traced back to Nietzsche's insightful thought on translation, so closely related to his postmodern philosophy, which is characterized by his perspectivism, revaluation, and intervening conquest, to some extent.

Obviously, Nietzsche's postmodern philosophy about translation, by uncrowning the author as God of the text, liberating the translator, and enlarging the space of multi-interpretative signifiers, has greatly inspired those who followed after him. Having played an essential role in the development of postmodern translation studies, his insights have also helped to extricate translators from the ethical dilemma of their re-creativity and have encouraged them to develop their subjectivity. Consequently, the horizons of translation studies were broadened. Nietzsche's legacy has markedly challenged the conventional, linguistic-based, prescriptive view of translation, governed by the norms of domesticating fluency, accuracy, and naturalness in focus. It paved the way to a broader, more descriptive, philosophical, and cultural perspective in translation studies, one which pays most attention to strategies such as rewriting, adaption, mistranslation, and especially foreignization. The latter aims to resist the cultural hegemony inherent in domestication in favor of showcasing cultural difference and other(ness). Some of these theorists are also translators, who can not only bridge the gap between theory and practice, but also serve as models for other practitioners.

However, while abandoning the prevalent text/author-centeredness, Nietzsche's idea entrusts the translator reader-as-translator with unrestricted will to power. Not without consequence, this has partly led to the later deconstructionist extremes seen in translation studies and to the overspreading of meaning's nihilism embodied by such ideas as différance (Derrida 1972/1982). These govern the production of textual meaning, which is bound up in a supplementary play of meaning that defies semantic reduction. Derrida, namely, endows the translator "with the right, even the duty to 'abuse' the source text" (von Flowtow 1991: 80). He calls for the violation of the rules/laws of writing and issues an epistemological challenge to established, definitive truths, doing so in a Nietzschean, postmodern way. All of this shows us that 
Nietzsche's postmodern thinking on translation (studies) can offer great insight, on the one hand. On the other, it truly invites and compels us to rethink such confusions with more reason, but also to more actively and urgently answer the Bakhtinian call for "dialogism" (Bakhtin 1975/1981), which is expected to bridge these gaps in some way.

\section{ACKNOWLEDGMENTS}

The author wishes to thank the anonymous peer reviewers and editors for their insightful comments. Any remaining errors, however, are my own.

\section{NOTES}

1. Pound, Ezra (1951): The Letters of Ezra Pound, 1907-1941. (Edited by Douglass D. PAIGE) London: Faber and Faber, 185.

2. Pound, Ezra (1915): Cathay. London: Elkin Mathews.

\section{REFERENCES}

Bakhtin, Mikhail M. (1975/1981): The Dialogic Imagination. Austin: University of Texas Press. Barthes, Roland (1971/1977): From Work to Text. In: Roland Barthes. Image, Music, Text. (Translated from French by Stephen Heath) London: Fontana Press, 155-164.

Barthes, Roland (1967/1977): The Death of the Author. In: Roland BARTHes. Image, Music, Text. (Translated from French by Stephen Heath) London: Fontana Press, 142-148.

Benjamin, Andrew (1989): Translation and the Nature of Philosophy: A New Theory of Words. London/New York: Routledge.

Benjamin, Walter (1923/1968): The Task of the Translator. In: Walter Benjamin. Illuminations. (Edited by Hannah Arendt and translated from German by Harry ZoHn) New York: Schocken Books, 69-82.

Benjamin, Walter (1916/1997): On Language as Such and on the Language of Man. (Translated from German by Edmund Јернсотт) In: Walter Benjamin. Walter Benjamin: Selected Writings. (Edited by Marcus Bullock and Michael W. Jennings) Vol. 1. 1913-1926. Cambridge/London: Belknap Press of Harvard University Press, 62-74.

Chilton, Randolph and Gilbertson, Carol (1990): Pound's "Metro' Hokku”: The Evolution of an Image. Twentieth Century Literature. 36(2):225-236.

Cohen, Margaret (2004): Benjamin's Phantasmagoria: The Arcades Project. In: David S. FerRIs, ed. The Cambridge Companion to Walter Benjamin. Cambridge: Cambridge University Press, 199-220.

Croce, Benedetto (1915/1921): Theory and History of Historiography. (Translated from German by Douglas Ainsuie) London: George G. Harrap.

Davidson, Donald (1974): Belief and the Basis of Meaning. Synthese. 27:309-323.

Davidson, Donald (1985/1996): A Nice Derangement of Epitaphs. In: Aloysius P. Martinich, ed. The Philosophy of Language. Oxford/New York: Oxford University Press, 465-475.

De Man, Paul (1986/2002): Conclusions: Walter Benjamin's “The Task of the Translator." In: Paul De Man. The Resistance to Theory. Manchester: Manchester University Press, 73-105.

Deмвo, Lawrence S. (1963): The Confucian Odes of Ezra Pound: A Critical Appraisal. Berkeley: University of California Press.

Derrida, Jacques (1967/1973): Speech and Phenomena. (Translated from French by David B. Allison and Newton Garver) Evanston: Northwestern University Press.

Derrida, Jacques (1972/1982): Différance. In: Jacques Derrida. Margins of Philosophy. (Translated from French by Alan BAss) Chicago/London: Chicago University Press, 1-27.

Derrida, Jacques (1982/1985): The Ear of the Other. (Translated from French by Peggy Kamuf) New York: Schocken Books. 
Derrida, Jacques (1999/2001): What Is a "Relevant" Translation? (Translated by Lawrence Venuti) Critical Inquiry. 27(2):174-200.

Derrida, Jacques (1985/2007): Des tours de Babel. (Translated from French by Joseph F. Graham) In: Jacques Derrida. Psyche: Inventions of the Other (Edited by Peggy Kamuf and Elizabeth G. RottenberG) Vol. I. Stanford: Stanford University Press, 191-225.

Eliot, Thomas S. (1934): Introduction. In: Ezra Pound. Selected Poems. London: Faber \& Faber, vii-xxv.

Erickson, Millard J. (2001): Truth or Consequences: The Promise and Perils of Postmodernism. Downers Grove: InterVarsity Press.

FoucAult, Michel (1967/1998): Nietzsche, Freud, Marx. (Translated from French by Jon AndERson and Gary Hentzi) In: Michel Foucault. Aesthetics, Method, and Epistemology. (Edited by James D. Faubion) Vol. 2. New York: The New Press, 269-278.

Foucault, Michel (1969/1998): What Is an Author? (Translated from French by Josue V. Harari) In: Michel Foucault. Aesthetics, Method, and Epistemology. (Edited by James D. Faubion) Vol. 2. New York: The New Press, 205-222.

France, Peter (1996): Review of Pour une critique des traductions: John Donne by Antoine Berman [1995, Paris: Gallimard] and of The Translator's Invisibility by Lawrence Venuti [1995, London/New York: Routledge]. Translation and Literature. 5(1):111-116.

Gadamer, Hans-Georg (1967/1976): Philosophical Hermeneutics. (Edited and translated from German by David E. LINGE) Los Angeles/London: University of California Press.

Gadamer, Hans-Georg (1960/2004): Truth and Method. (Translated from German by Joel Weinshermer and Donald G. Marshall) London/New York: Continuum.

GentZler, Edwin (1993/2004): Contemporary Translation Theories. Shanghai: Shanghai Foreign Language Education Press.

GondeK, Hans-Dieter (1997): Logos und Übersetzung [Logos and translation]. In: Alfred Hirsch, ed. Übersetzung und Dekonstruktion [Translation and deconstruction]. Frankfurt: Suhrkamp, 263-348.

Guignon, Charles B. (1993): Introduction. In: Charles B. Guignon, ed. The Cambridge Companion to Heidegger. Cambridge: Cambridge University Press, 1-41.

Habermas, Jürgen (1985/1987): The Philosophical Discourse of Modernity. (Translated from German by Frederick Lawrence) Cambridge: MIT Press.

Hegel, Friedrich (1807/1998): Philosophy of Absolute Spirit. In: Friedrich Hegel. The Hegel Reader. (Edited by Stephen Houlgate). Malden: Blackwell, 417-528.

Heidegger, Martin (1954): Was heißt Denken? [What is called thinking?]. Tübingen: Max Nlemeyer Verlag.

Heidegger, Martin (1950/1984): The Anaximander Fragment. In: Martin Heidegger. Early Greek Thinking. (Translated by David F. Krell and Frank A. CAPUzzi) New York: Harper Collins, 13-58.

Heidegger, Martin (1939/1991): The Will to Power as Knowledge. In: Martin Heidegger. Nietzsche. (Edited by David F. Krell and translated from German by Joan Stambaugh, David F. Krell, and Frank A. Capuzzi) Vol. 3. The Will to Power as Knowledge and as Metaphysics. New York: Harper Collins, 1-158.

Heidegger, Martin (1927/2001): Being and Time. (Translated from German by John MacquarRIE and Edward RoBInson) Oxford: Blackwell.

Hermans, Theo (1994): Translation between Poetics and Ideology. Review of Translation, Rewriting and the Manipulation of Literary Fame by André Lefevere [1992, London/New York: Rouledge], of Translation/History/Culture by André Lefevere [1992, London/New York: Routledge], of Translating Literature by André Lefevere [1992, New York: Modern Language Association of America], and of Translation and Translation Theory in Seventeeth-Century Germany by James Hardin [1992, Amsterdam/Atlanta: Rodopi]. Translation and Literature. 3:138-145.

Horkheimer, Max and Adorno, Theodor W. (1947/2002): Dialectic of Enlightenment: Philosophical Fragments. (Edited by Gunzelin S. NOERR and translated from German by Edmund Jернсотт) Stanford: Stanford University Press. 
Lefevere, André (1992a): Translation, Rewriting and the Manipulation of Literary Fame. London/New York: Routledge.

Lefevere, André, ed. (1992b): Translation/History/Culture. London/New York: Routledge.

Lefevere, André (1992c): Translating Literature: Practice and Theory in a Comparative Literature Context. New York: Modern Language Association of America.

Lefevere, André (1995): Introduction: Comparative Literature and Translation. Comparative Literature. 47(1):1-10.

Miner, Earl (1966): The Japanese Tradition in British and American Literature. Princeton: Princeton University Press.

Munday, Jeremy (2001): Introducing Translation Studies: Theories and Implications. London/ New York: Routledge.

Nietzsche, Friedrich (1901/1910): The Will to Power. (Translated from German by Anthony M. Ludovici) London: George Allen \& Unwin.

Nietzsche, Friedrich (1886/1911): Beyond Good and Evil. (Translated from German by Helen ZimMERn) Edinburgh/London: T. N. Foulis.

Nietzsche, Friedrich (1896/1911): On Truth and Falsity in Their Ultramoral Sense. In: Oscar Levy, ed. Early Greek Philosophy and Other Essays. (Translated from German by Maximilian A. MugGe) New York: Macmillan, 171-192.

Nietzsche, Friedrich (1885/1923): Thus Spake Zarathustra. (Translated by Thomas Common) Edinburgh/London: T. N. Foulis.

Nietzsche, Friedrich (1895/1954): The Antichrist. In: Friedrich Nietzsche. The Portable Nietzsche. (Edited and translated from German by Walter Kaufmann) New York: Viking Press, 565-656.

Nietzsche, Friedrich (1889/1954): Twilight of the Idols. In: Friedrich Nietzsche. The Portable Nietzsche. (Edited and translated from German by Walter Kaufmann) New York: Viking Press, 463-563.

Nietzsche, Friedrich (1901/1968): The Will to Power. (Translated from German by Walter Kaufmann) New York: Random House.

Nietzsche, Friedrich (1882/1974): The Gay Science. (Translated from German by Walter Kaufmann) New York: Random House.

Pearson, K. Ansell and Large, Duncan, eds. (2006): The Nietzsche Reader. Malden/Oxford: Blackwell.

Pound, Ezra (1914): Vorticism. Fortnightly Review. 96(1): 461-471.

Pound, Ezra (1934/1954): Calvacanti. In: Ezra Pound. Literary Essays of Ezra Pound. (Edited by Thomas S. ЕLIOT) London: Faber \& Faber, 149-200.

Pound, Ezra (1929/1954): How to Read. In: Ezra Pound. Literary Essays of Ezra Pound. (Edited by Thomas S. ЕLIOT) London: Faber \& Faber, 15-40.

Pound, Ezra (1973): Selected Prose: 1909-1965. (Edited by William Cookson) London: Faber \& Faber.

Pound, Ezra (1929/2000): Guido's Relations. In: Lawrence Venuti, ed. The Translation Studies Reader. London/New York: Routledge, 26-33.

Preda, Roxana (2001): Ezra Pound's (Post)Modern Poetics and Politics. New York: Peter Lang.

Quine, Willard V. (1960): Word and Object. Cambridge: MIT Press.

Quine, Willard V. (1969): Ontological Relativity and Other Essays. New York: Columbia University Press.

Quine, Willard V. (1987): Indeterminacy of Translation Again. The Journal of Philosophy. 84(1):510.

Quine, Willard V. (1992): Pursuit of Truth. Cambridge: Harvard University Press.

Ricoeur, Paul (2006): On Translation. (Translated from French by Eileen Brennan) London/ New York: Routledge.

Robinson, Dave (1999): Nietzsche and Postmodernism. Cambridge: Icon Books.

Roy Le, Nicholas (2003): Jacques Derrida. London/New York: Routledge. 
SсHACHT, Richard (2002): Nietzsche. London/New York: Routledge.

Schopenhauer, Arthur (1969): The World as Will and Representation. Vol. I. (Translated from German by Eric F. J. PAYNe) New York: Dover Publication.

SeArLe, John R. (1987): Indeterminacy, Empiricism, and the First Person. The Journal of Philosophy. 84(3):123-146.

SpIVAK, Gayatri C. (1997): Translator's Preface. In: Jacques DerridA. Of Grammatology. (Translated from French by Gayatri C. SPIVAK) Baltimore/London: Johns Hopkins University Press, ix-lxxxvii.

Steiner, George (1975/1998): After Babel: Aspects of Language and Translation. $3^{\text {rd }}$ ed. Oxford: Oxford University Press.

Strong, Tracy B. (1985): Text and Pretexts: Reflections on Perspectivism in Nietzsche. Political Theory. 13(2):164-182.

Venuti, Lawrence (1992): Rethinking Translation - Discourse, Subjectivity, Ideology. London/ New York: Routledge.

Venuti, Lawrence (1995): The Translator's Invisibility: A History of Translation. London/New York: Routledge.

Venuti, Lawrence (1997): Unequal Developments: Current Trends in Translation Studies. Comparative Literature. 49(4):360-368.

Venuti, Lawrence (1998): The Scandals of Translation: Towards an Ethics of Difference. London/ New York: Routledge.

VenUti, Lawrence (2001): Introduction. Critical Inquiry. 27(2):169-173.

Venuti, Lawrence (2013): Translation Changes Everything: Theory and Practice. London/New York: Routledge.

von Flotow, Luise (1991): Feminist Translation: Contexts, Practices, Theories. TTR. 4(2):69-84.

XIE, Ming (1999): Pound as Translator. In: Ira B. NADEL, ed. The Cambridge Companion to Ezra Pound. Cambridge: Cambridge University Press, 204- 223. 